\title{
Mechanism of Action and Efficacy of Seed Meal-Induced Pathogen Suppression Differ in a Brassicaceae Species and Time-Dependent Manner
}

\author{
Mark Mazzola, Jack Brown, Antonio D. Izzo, and Michael F. Cohen
}

First, third, and fourth authors: United States Department of Agriculture-Agricultural Research Service, 1104 N. Western Ave., Wenatchee, WA 98801; and second author: Department of Plant, Soil and Entomological Sciences, University of Idaho, Moscow 83844-2339. Current address of M. F. Cohen: Department of Biology, Sonoma State University, 1801 East Cotati Ave., Rohnert Park, CA 94928. Accepted for publication 3 November 2006.

\begin{abstract}
Mazzola, M., Brown, J., Izzo, A. D., and Cohen, M. F. 2007. Mechanism of action and efficacy of seed meal-induced pathogen suppression differ in a Brassicaceae species and time-dependent manner. Phytopathology 97:454-460.

The effect of seed meals derived from Brassica juncea, B. napus, or Sinapis alba on suppression of soilborne pathogens inciting replant disease of apple was evaluated in greenhouse trials. Regardless of plant source, seed meal amendment significantly improved apple growth in all orchard soils; however, relative differences in pathogen suppression were observed. All seed meals suppressed root infection by native Rhizoctonia spp. and an introduced isolate of Rhizoctonia solani AG-5, though B. juncea seed meal often generated a lower level of disease control relative to other seed meal types. When introduction of the pathogen was delayed until 4 to 8 weeks post seed meal amendment, disease suppression was associated with proliferation of resident Streptomyces spp. and not qualitative or quantitative attributes of seed meal glucosinolate content. Using the same

experimental system, when soils were pasteurized prior to pathogen infestation, control of $R$. solani was eliminated regardless of seed meal type. In the case of B. juncea seed meal amendment, the mechanism of $R$. solani suppression varied in a temporal manner, which initially was associated with the generation of allylisothiocyanate and was not affected by soil pasteurization. Among those tested, only B. juncea seed meal did not stimulate orchard soil populations of Pythium spp. and infection of apple roots by these oomycetes. Although application of $B$. napus seed meal alone consistently induced an increase in Pythium spp. populations, no significant increase in Pythium spp. populations was observed in response to a composite $B$. juncea and $B$. napus seed meal amendment. Suppression of soil populations and root infestation by Pratylenchus spp. was dependent upon seed meal type, with only $B$. juncea providing sustained nematode control. Collectively, these studies suggest that use of a composite $B$. juncea and $B$. napus seed meal mixture can provide superior control of the pathogen complex inciting apple replant disease relative to either seed meal used alone.
\end{abstract}

Biologically based treatments such as the use of soil organicresidue amendments have been promoted as alternatives to the use of broad-spectrum biocides for the management of soilborne plant pathogens (16,30). Although such an approach has exhibited some practicality in certain environments, such as container-based or greenhouse production systems (27), its application in largescale soil-based systems has failed to attain a level of efficacy and consistency required for extensive adoption. The production and yield of various bioactive chemistries, including isothiocyanates (ITCs), has encouraged studies exploring the pest control efficacy of Brassicaceae plant residues applied either through soil incorporation of a cover crop or direct amendment of plant residues. ITCs have a broad spectrum of biocidal activity; therefore, investigators have focused on the use of Brassicaceae plant residues as a "biofumigant," where incorporation of plant residue into soil ultimately results in the release of active glucosinolate hydrolysis products $(1,6,15)$. However, a growing body of evidence suggests that certain of these plant residues may operate in the suppression of fungal pathogens via a different, as yet unidentified, mechanism. For example, reports exist of the effective use of Brassica napus residues to control soilborne plant pathogens $(11,24,25)$, even though separate reports suggest that these plant

Corresponding author: M. Mazzola; E-mail address: mazzola@tfrl.ars.usda.gov

doi:10.1094/PHYTO-97-4-0454

This article is in the public domain and not copyrightable. It may be freely reprinted with customary crediting of the source. The American Phytopathological Society, 2007. residues yield ITCs having relatively low antimicrobial activity (19). Potter et al. (31) observed no relationship between total glucosinolate content or any individual glucosinolate in leaf tissues from different Brassica spp. applied as an amendment and suppression of the lesion nematode Pratylenchus neglectus. Likewise, the protective effect of Brassicaceae residues against fungal infection of pea plants was found to increase for weeks after ITCs had been lost from the soil by either volatilization or microbial degradation $(17,29,35)$.

Findings from our previous studies demonstrated that attributes other than glucosinolate hydrolysis products contribute to the suppression of certain apple root pathogens in response to B. napus seed meal (rapeseed meal [RSM]) amendment $(10,11)$. Control of Rhizoctonia solani and $P$. penetrans was obtained via the incorporation of RSM regardless of the glucosinolate content of the amendment (24). RSM is a high-nitrogen-containing product, and suppression of lesion nematodes may be attributed to the oftencited nematicidal or nematistatic effect of nitrogenous amendments $(28,32)$. However, RSM-induced control of $R$. solani does not appear to operate via chemical inhibition of hyphal growth in soil (11) but, rather, through an influence on the resident soil microbial community, as evidenced by the fact that pasteurization of RSM-amended soil eliminated control of apple root infection by an introduced isolate of this fungal pathogen (10). The biological factor mediating disease control apparently varies in a temporal manner. Experimental inhibition of nitrification and the associated emission of nitric oxide (NO) limited disease control immediately after application of the amendment, but did not impact the efficacy of RSM when introduction of the pathogen 
was delayed until well beyond the peak period of NO release (10).

In Washington, apple replant disease is incited by a biological consortium of fungal pathogens and plant-parasitic nematodes (21). Effective use of an individual organic amendment for the control of such a diverse biological complex seems improbable. Although RSM amendment can provide significant control of replant disease in field trials, a post plant application of mefenoxam was required due to the stimulatory impact of the amendment on populations of Pythium spp. and infection of apple roots by these oomycetes (25). Given the breadth of glucosinolates produced by Brassicaceae plant species and the corresponding biological activity of the resulting ITCs (6), it is likely that an alternative seed meal exists which will not elicit the stimulatory effect on Pythium populations observed in response to RSM amendment.

The goals of the current study were to (i) investigate the potential of various Brassicaceaous seed meal amendments, or combinations thereof, to suppress multiple elements of the biological complex that incites apple replant disease; (ii) examine and assess whether disease control elicited via these seed meals differed mechanistically; and (iii) determine the temporal nature of disease control yielded through the use of $B$. juncea seed meal, which generates a biologically active volatile isothiocyanate $(1,6,20)$.

\section{MATERIALS AND METHODS}

Orchard soils. Soils utilized in these studies were collected from the Columbia View Experimental (CV) orchard, Orondo, WA; the Wenatchee Valley College Research and Demonstration (WVC) orchard, East Wenatchee, WA; and a commercial (GC) orchard, Manson, WA. Characteristics of these soils, both physical and biological, have been described $(21,22,24)$. Soil $\mathrm{pH}$ ranged from 6.9 (WVC) to 7.1 (CV) (Cascade Analytical, Wenatchee, WA). Disease development at the CV and WVC orchards has been attributed to the activity of a fungal complex whereas, at the GC orchard, the lesion nematode P. penetrans contributed to growth suppression in concert with the same fungal complex. Soils were collected from the root zone of established trees at each site in October 2003 and October 2004 in the manner previously described (24).

Seed meals. Seed meals used in these studies were obtained from B. napus cv. Dwarf Essex (DE; Montana Specialty Mills, Great Falls, MT), B. napus cv. Athena (AT) (4), B. juncea cv. Pacific Gold (PG) (3), and Sinapis alba cv. IdaGold (IG) (2). Seed meals varied in glucosinolate profile and content. B. napus DE $\left(21.8 \mu \mathrm{mol} \mathrm{g}{ }^{-1}\right.$ of defatted seed meal $)$ and AT $\left(25.4 \mu \mathrm{mol} \mathrm{g} \mathrm{g}^{-1}\right.$ of defatted seed meal) possessed the lowest content, of which 2hydroxy-3-butenyl and 4-pentenyl, respectively, were the dominant gluocosinolates. S. alba IG and B. juncea PG both possessed higher glucosinolate levels, 244 and $303 \mu \mathrm{mol} \mathrm{g}{ }^{-1}$ of defatted seed meal, respectively. 2-Propenyl (allyl) composed $>99 \%$ of the glucosinolate contained in $B$. juncea PG whereas, for $S$. alba IG, $p$-hydroxylbenzyl glucosinolate represented $>95 \%$ of the total content. Content of selected minerals were determined for each seed meal (Soiltest Farm Consultants, Inc., Moses Lake, WA). Mineral content for seed meals were as follows; nitrogen, 5.57 to $6.84 \%$; phosphorous, 1.21 to $1.39 \%$; potassium, 1.11 to $1.50 \%$; and sulfur, 0.86 to $1.59 \%$.

Effect of seed meals on growth of apple and disease development. Seed meal was incorporated into soils at a concentration of $0.5 \%$ ( $\mathrm{vol} / \mathrm{vol})$. Soils that were either nontreated (control) or amended with seed meal were decanted into 3.8-liter plastic pots and incubated in the greenhouse for 8 weeks at $22 \pm$ $3^{\circ} \mathrm{C}$. This delay between soil amendment and planting was established to circumvent potential phytotoxic effects from volatile allelochemicals produced as a result of glucosinolate hydrolysis. In addition, this protocol allowed for sufficient amplification of resident Streptomyces spp., a community previously shown to be associated with pathogen suppression $(10,11)$. Because seed meals contain significant, though variable, additions of plantavailable $\mathrm{N}, 100 \mathrm{ml}$ of Hoagland solution no. 1 (macronutrients only), which supplies $\mathrm{N}$ only in the nitrate form, was applied to each control pot. At completion of the incubation period, 8-weekold Gala apple seedlings were planted into soils with five seedlings per pot and four replicate pots per treatment. Plants were harvested after 12 to 15 weeks of growth in the greenhouse. At harvest, seedling root systems were washed under a stream of tap water, and plant height, shoot weight, and root weight were determined. Relative colonization of Gala seedling roots by Pythium and Rhizoctonia spp. was determined as previously described (11).

Among orchard soils employed in this study, GC is the sole soil possessing significant numbers of the lesion nematode P. penetrans (21). Assays were conducted in this soil to determine the efficacy of individual seed meals in nematode suppression and the duration of the response. Soils were treated with the respective seed meals, decanted into 3.8-liter plastic pots with 16 pots per treatment, and incubated in the greenhouse as stated above. At completion of the incubation period, a 50-g soil sample was collected from each pot. Soil populations of $P$. penetrans were determined using the modified pie-pan modification of the Baermann funnel technique (12). One MM106 rootstock, which is highly supportive of $P$. penetrans reproduction (M. Mazzola, unpublished data), was planted into each pot and, for each treatment, eight plants were harvested at 3 months and the remaining rootstocks at 6 months after planting. At harvest, plant roots were washed with tap water, two 0.5-g root samples were collected from each tree, and $P$. penetrans populations were determined as described (21).

Effect of seed meals on $R$. solani AG-5 apple root infection. The capacity of Brassicaceae seed meals to suppress apple root infection by $R$. solani AG-5 was examined in artificially infested soils. $R$. solani AG-5 strain 5-104 initially was recovered from the roots of apple (Gala/M26) cultivated in a commercial orchard near Moxee, WA (21). Each seed meal (B. napus cvs. AT and DE, $S$. alba $\mathrm{IG}$, and $B$. juncea $\mathrm{PG}$ ) was applied individually to $\mathrm{CV}$ orchard soil at a rate of $0.5 \%(\mathrm{vol} / \mathrm{vol})$. Nontreated soil and seed meal-amended soils were placed in 3.8-liter plastic pots and incubated on a greenhouse bench. After 6 weeks, $10 \mathrm{R}$. solaniinfested oat seed, prepared as previously described (26), were placed in a circular pattern at a soil depth of $8 \mathrm{~cm}$. Soils were incubated overnight, and each pot then was planted with five 8-week-old Gala apple seedlings. Each treatment was represented by a total of five pots. Seedlings were harvested after 8 weeks, at which time plants were processed as described above and 10 root segments from each plant were plated onto water agar amended with ampicillin $\left(100 \mu \mathrm{g} \mathrm{ml}^{-1}\right)$ and streptomycin $\left(100 \mu \mathrm{g} \mathrm{ml}^{-1}\right)$. Agar plates were incubated at room temperature and examined after $48 \mathrm{~h}$ using a light microscope $(\times 100)$ for hyphal growth of R. solani.

Experiments were conducted to evaluate the role of indigenous soil microorganisms in the seed meal-induced suppression of Rhizoctonia root rot. WVC orchard soil was amended with the individual seed meals as described above and incubated at room temperature for 6 weeks. Pasteurized treatments were prepared by placing one-half of each of the respective soils in heat-resistant bags and exposing them to steam at $102^{\circ} \mathrm{C}$ for $3 \mathrm{~h}$. Soils were cooled overnight prior to repeating the steaming cycle. Infestation of native and pasteurized soils, growth conditions, plant processing, and assessment of root infection were conducted as above.

Streptomyces spp. numbers in seed meal-amended and nontreated soils were determined immediately prior to planting in all trials. Two 0.5 -g bulk soil samples were arbitrarily collected from each pot just prior to planting and at harvest. Soils were resuspended in $10 \mathrm{ml}$ of sterile distilled water and vortexed at highest speed for $60 \mathrm{~s}$. Serial dilutions of the soil suspension were 
plated onto 1/50th-strength trypticase soy agar. After $72 \mathrm{~h}$ of incubation at room temperature, colonies exhibiting a growth characteristic representative of members belonging to the genus Streptomyces were subjected to microscopic examination $(\times 100)$ for confirmation of identity and enumeration.

Temporal dynamic of $B$. juncea PG-induced control of $\boldsymbol{R}$. solani AG-5. The volatile isothiocyanate emanating from hydrolysis of the dominant glucosinolate (allyl-glucosinolate) produced by $B$. juncea $\mathrm{PG}$ is known to inhibit growth of $R$. solani (18). In studies described above, volatile isothiocyanates likely would have evacuated the soil system prior to introduction of the pathogen 6 weeks after seed meal amendment. Therefore, additional studies were conducted to assess the temporal nature of pathogen suppression and disease control in response to $B$. juncea PG soil amendment.

CV soil was amended with B. napus DE, S. alba $\mathrm{IG}$, or B. juncea $\mathrm{PG}$ at a rate of $0.5 \%(\mathrm{vol} / \mathrm{vol})$, and $7 \mathrm{~g}$ of amended or nontreated soil was placed in the base of a 5 -cm-diameter petri plate. Three $R$. solani AG-5 colonized oat grains were attached to the lid of the petri plate using double-sided adhesive tape and the plate was sealed using parafilm. Each treatment was represented by three replicate plates which were incubated at room temperature. After $24 \mathrm{~h}$, plates were unsealed, and oat grains were removed and placed on individual water agar plates amended with ampicillin $\left(100 \mu \mathrm{g} \mathrm{ml}^{-1}\right)$. Viability of $R$. solani was determined after $24 \mathrm{~h}$ of incubation at $22^{\circ} \mathrm{C}$ by measuring linear hyphal growth. Plates containing CV soils remained open for $15 \mathrm{~min}$ prior to attaching new oat inoculum to the lids and resealing the plates with parafilm. Plates again were incubated for $24 \mathrm{~h}$, at which time oat grains were removed and placed on water agar, with viability of $R$. solani determined as above.

$\mathrm{CV}$ orchard soil was amended with $B$. juncea seed meal as above 0 h, 24 h, or 4 weeks prior to infestation with $R$. solani AG5 . Amended and nontreated soils were decanted into conical tubes ( $21 \mathrm{~cm}$ in length by $4 \mathrm{~cm}$ in top diameter) with 10 tubes per soil treatment. Each tube was planted with one 4-week-old Gala apple seedling, with the lowest root being placed $3 \mathrm{~cm}$ above a single $R$. solani-infested oat grain. Plants were placed in an environmental growth chamber at a temperature regime of $24^{\circ} \mathrm{C}$, day, and $16^{\circ} \mathrm{C}$, night, with a 16 -h photoperiod. Plants were harvested after 2 weeks and infection rates were determined by plating 20 root segments from each plant on water agar and monitoring hyphal growth as described above. A study employing the 0 - and 24-h incubation periods prior to pathogen infestation also was conducted in pasteurized CV orchard soil using the same growth conditions.

Emission of allyl-isothiocyanate from $B$. juncea PGamended soil. The temporal pattern of allyl-ITC emission from B. juncea PG-amended CV orchard soil was monitored. B. juncea PG was added to $250 \mathrm{ml}$ of soil at a concentration of $0.5 \%$ ( $\mathrm{vol} / \mathrm{vol}$; seed meal at $3.7 \mathrm{mg} \mathrm{ml}^{-1}$ of soil) and soil was placed in a 0.946-liter mason jar, with three replicate sample jars. One hour prior to each sampling, the jar tops were fastened with a lid containing a rubber septum. The head space was sampled by piercing the septum with a 3.8-cm-long 18-gauge needle and extracting a 1 -ml volume which was injected into a Hewlett-Packard 5880A series gas chromatograph. The gas chromatograph was equipped with a CP-PoraBond Q fused silica capillary column $(10 \mathrm{~m}$ by $0.32 \mathrm{~mm}$; Varian, Palo Alto, CA) with injector and detector temperatures set at 100 and $250^{\circ} \mathrm{C}$, respectively. Allyl-ITC was eluted using a program which increased column temperature from 125 to $175^{\circ} \mathrm{C}$ so that the peak was emitted within 3 min. Concentrations were determined by comparison to a standard curve generated using a pure allyl-ITC solution (Sigma-Aldrich, St. Louis).

Impact of composite seed meal amendment on Pythium spp. populations and root infection. Amendment of soil with $B$. napus seed meal has consistently induced a stimulation of resident Pythium populations $(10,24)$. Studies were conducted to determine whether a composite amendment consisting of B. napus DE and $B$. juncea $\mathrm{PG}$ altered the response in Pythium spp. populations and infection of apple planted in treated soils. CV and GC soils were amended with seed meal at a total concentration of $0.5 \%$ but at different ratios of $B$. napus DE:B. juncea $\mathrm{PG}$, as follows: 1:0, 2:1, 1:1, 1:2, and 0:1. Soils did not receive an extended incubation period as in previous trials but, rather, were dispensed immediately into conical tubes, and each cone was planted with one 8-week-old apple seedling. Nontreated soil was included as the control and each treatment was represented by 10 plants arranged in a completely randomized design. Plants were grown in controlled environment chambers with a $16-\mathrm{h}$ photoperiod and a day-and-night temperature regime of 24 and $16^{\circ} \mathrm{C}$, respectively.

Pythium spp. soil populations were determined at $0,3,7$, and 14 days post planting. A 1-g soil sample was collected from four randomly selected tubes per treatment. Soil was resuspended in $10 \mathrm{ml}$ of sterile distilled $\mathrm{H}_{2} \mathrm{O}$, vortexed for $60 \mathrm{~s}$, and serial dilutions were plated onto Pythium semiselective medium (PSSM) (24). Plants were harvested after 2 weeks and processed as described above. Ten root segments, 0.5 to $1.0 \mathrm{~cm}$ in length, from each seedling were excised randomly from each Gala seedling and plated on PSSM. Plates were incubated at room temperature and examined after 24 and $48 \mathrm{~h}$ to determine relative root infection and estimate soil populations of Pythium spp. From the remaining root tissues, lesion nematode root populations were determined as described (21).

Data analysis. Data were analyzed using SigmaStat (version 3.1; Systat Software Inc., Point Richmond, CA). Percent root infection data and soil population data were transformed to arcsine-square root and $\log _{10}$ values, respectively, prior to conducting analysis of variance, and means separation was performed using the Student-Newman-Keuls method. All experiments were conducted twice. Data reported are from the initial experiment, and significant differences between experiments are described in the text.

\section{RESULTS}

Impact of amendments on apple growth and disease suppression. Individual seed meal amendments enhanced Gala apple seedling root and shoot biomass relative to the nontreated control

TABLE 1. Effect of Brassicaceae seed meal amendment on growth of 'Gala' apple seedlings in replant orchard soils

\begin{tabular}{|c|c|c|c|c|c|c|}
\hline \multirow[b]{3}{*}{ Treatment ${ }^{\mathrm{y}}$} & \multicolumn{6}{|c|}{ Orchard $^{\mathrm{z}}$} \\
\hline & \multicolumn{2}{|c|}{$\mathrm{CV}$} & \multicolumn{2}{|c|}{ GC } & \multicolumn{2}{|c|}{ WVC } \\
\hline & Root wt (g) & Shoot wt (g) & Root wt (g) & Shoot wt (g) & Root wt (g) & Shoot wt (g) \\
\hline $\mathrm{DE}$ & $0.97 \mathrm{~b}$ & $3.98 \mathrm{~b}$ & $1.47 \mathrm{~b}$ & $6.13 \mathrm{c}$ & $0.71 \mathrm{a}$ & $2.07 \mathrm{~b}$ \\
\hline AT & $0.94 \mathrm{~b}$ & $3.67 \mathrm{~b}$ & $1.26 \mathrm{~b}$ & $4.94 \mathrm{bc}$ & $0.69 \mathrm{a}$ & $2.34 \mathrm{~b}$ \\
\hline IG & $1.04 \mathrm{~b}$ & $4.26 \mathrm{~b}$ & $1.45 \mathrm{~b}$ & $5.73 \mathrm{bc}$ & $0.67 \mathrm{a}$ & $2.49 \mathrm{~b}$ \\
\hline PG & $0.75 \mathrm{ab}$ & $4.03 \mathrm{~b}$ & $1.28 \mathrm{~b}$ & $4.60 \mathrm{~b}$ & $1.13 \mathrm{~b}$ & $2.68 \mathrm{~b}$ \\
\hline
\end{tabular}

y $\mathrm{DE}=$ Brassica napus cv. Dwarf Essex, AT = B. napus cv. Athena, $\mathrm{IG}=$ Sinapis alba cv. IdaGold, and PG = B. juncea cv. Pacific Gold.

${ }^{z}$ Orchard designations: CV, Columbia View Experimental Orchard, Orondo, WA; GC, commercial orchard, Manson, WA; and WVC, Wenatchee Valley College Research and Demonstration Orchard, E. Wenatchee, WA. Means in a column followed by the same letter are not significantly different $(P>0.05 ; n=4)$. 
regardless of soil in which assays were conducted (Table 1). Although shoot growth was enhanced consistently across orchard soils tested, in certain instances plants grown in B. juncea PGamended soils exhibited superior root biomass production relative to B. napus or S. alba seed meals. In one experiment conducted in the WVC orchard, a significant increase in seedling root biomass was observed only in response to B. juncea PG amendment (Table $1)$. When repeated in WVC soil, all seed meal amendments significantly improved root and shoot biomass relative to the control (data not shown). A similar finding was obtained in CV soil, in which seedling root biomass did not differ among seed meal treatments in one experiment (Table 1); however, in a second experiment, B. juncea PG amendment resulted in seedling root biomass that was significantly greater than that obtained in $B$. napus AT- $(P=0.009)$ or $S$. alba IG- $(P=0.005)$ amended soil.

Among those examined, only GC orchard soil possessed lesion nematode populations considered capable of suppressing apple growth (21). Application of any of the three Brassicaceae seed

TABLE 2. Effect of Brassicaceae seed meal amendment on recovery of Pratylenchus penetrans recovered from soil and roots of MM106 rootstock in a commercial orchard in Manson, WA

\begin{tabular}{lccc}
\hline & \multicolumn{3}{c}{ P. penetrans $\mathrm{g}^{-1}$ of soil } \\
\cline { 2 - 4 } Treatment & Preplant & 3 months post plant & 6 months post plant \\
\hline Control & $217 \mathrm{~b}$ & $115 \mathrm{~b}$ & $643 \mathrm{c}$ \\
DE & $19 \mathrm{a}$ & $16 \mathrm{a}$ & $281 \mathrm{~b}$ \\
AT & $5 \mathrm{a}$ & $11 \mathrm{a}$ & $177 \mathrm{~b}$ \\
IG & $7 \mathrm{a}$ & $1 \mathrm{a}$ & $246 \mathrm{~b}$ \\
PG & $1 \mathrm{a}$ & $4 \mathrm{a}$ & $2 \mathrm{a}$ \\
\hline
\end{tabular}

${ }^{\mathrm{y}} \mathrm{DE}=$ Brassica napus cv. Dwarf Essex, AT $=$ B. napus cv. Athena, $\mathrm{IG}=$ Sinapis alba cv. IdaGold, and PG $=B$. juncea $\mathrm{cv}$. Pacific Gold.

${ }^{\mathrm{z}}$ Means in a column followed by the same letter are not significantly different ( $P>0.05$; soil populations, $n=16$; root populations, $n=8)$.

TABLE 3. Effect of Brassicaceae seed meal amendment on percent root infection by resident Pythium spp. for 'Gala' seedlings grown in replant orchard soils

\begin{tabular}{lccl}
\hline & \multicolumn{3}{c}{ Orchard $^{\mathrm{z}}$} \\
\cline { 2 - 4 } Treatment $^{\mathrm{y}}$ & $\mathrm{CV}$ & $\mathrm{GC}$ & WVC \\
\hline Control & $12.5 \mathrm{a}$ & $13.0 \mathrm{a}$ & $15.0 \mathrm{a}$ \\
DE & $45.0 \mathrm{~b}$ & $43.5 \mathrm{~b}$ & $55.5 \mathrm{~b}$ \\
AT & $51.0 \mathrm{~b}$ & $68.5 \mathrm{c}$ & $68.5 \mathrm{bc}$ \\
IG & $49.5 \mathrm{~b}$ & $77.5 \mathrm{c}$ & $78.0 \mathrm{c}$ \\
PG & $7.0 \mathrm{a}$ & $11.0 \mathrm{a}$ & $20.5 \mathrm{a}$ \\
\hline
\end{tabular}

${ }^{\mathrm{y}} \mathrm{DE}=$ Brassica napus cv. Dwarf Essex, AT $=$ B. napus cv. Athena, $\mathrm{IG}=$ Sinapis alba cv. IdaGold, and $\mathrm{PG}=B$. juncea cv. Pacific Gold.

${ }^{z}$ Orchard designations: CV, Columbia View Experimental Orchard, Orondo, WA; GC, commercial orchard, Manson, WA; and WVC, Wenatchee Valley College Research and Demonstration Orchard, E. Wenatchee, WA. Means in a column followed by the same letter are not significantly different $(P>$ $0.05 ; n=4)$. meals significantly reduced numbers of $P$. penetrans recovered from GC orchard soil immediately prior to planting (Table 2). Lesion nematode populations recovered at 3 months post planting from the roots of MM106 rootstock grown in seed meal-amended soils were significantly lower than those recovered from MM106 rootstock planted in nontreated orchard soil, and there were no significant differences among seed meal treatments. However, at 6 months post planting, lesion nematode numbers recovered from roots of MM106 rootstock grown in B. juncea PG soil were significantly lower than those obtained from plants grown in B. napus DE-, S. alba IG-, or B. napus AT-amended soils (Table 2).

With the exception of $B$. juncea PG, populations of Pythium spp. in orchard soil increased significantly in response to seed meal amendments. For all three orchards, Pythium spp. numbers increased from $<60$ to $>500$ propagules $\mathrm{g}^{-1}$ of soil in response to amendment with either $B$. napus $\mathrm{AT}, B$. napus $\mathrm{DE}$, or $S$. alba $\mathrm{IG}$, with the greatest increase observed in GC orchard soils where populations were $>4,000 \mathrm{CFU} \mathrm{g}^{-1}$ of soil at planting. Pythium spp.

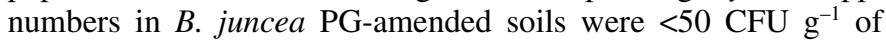
soil, which was not significantly different from the nontreated controls. Relative root infection of apple seedlings grown in these orchard soils corresponded with the increase in Pythium spp. soil populations induced by seed meal amendment. Root infection frequency by Pythium spp. increased from $\approx 13 \%$ for seedlings grown in nontreated soils to $\approx 45 \%$ or higher for seedlings grown in B. napus AT-, B. napus DE-, or S. alba IG-amended soil (Table 3). Pythium spp. root infection for plants grown in B. juncea PGamended soils was not altered relative to the nontreated control in any of the orchard soils examined.

Rhizoctonia spp. were recovered consistently from roots of Gala seedlings planted in CV orchard soil, infrequently from seedlings grown in WVC orchards oils, and were not isolated from those grown in GC orchard soil. Rhizoctonia spp. were recovered at a frequency of $25 \%$ from seedlings grown in nontreated CV orchard soil. All seed meal amendments significantly $(P<0.001)$ suppressed Rhizoctonia spp. root infection of seedlings grown in $\mathrm{CV}$ orchard soil, with the reduction in root infection ranging from $48 \%$ (B. juncea $\mathrm{PG}$ ) to $80 \%$ ( $S$. alba $\mathrm{IG}$ ), and there were no significant differences among seed meal treatments (data not shown).

Effect of seed meal amendments on apple root infection by $\boldsymbol{R}$. solani AG-5. In assays conducted in CV orchard soil, application of seed meal 6 weeks prior to pathogen infestation and planting resulted in elevated Streptomyces spp. numbers and consistently suppressed infection of apple seedling roots by $R$. solani AG-5 (Table 4). However, when the assay was conducted in WVC orchard soil, although all seed meal amendments suppressed root infection relative to the nontreated control, B. juncea $\mathrm{PG}$ treatment was less effective than B. napus DE soil amendment. Regardless of seed meal type, pasteurization of amended soil prior to introduction of $R$. solani AG-5 inoculum

TABLE 4. Effect of Brassicaceae seed meal amendment on soil populations of Streptomyces spp. and infection of 'Gala' seedling roots by Rhizoctonia solani AG5 in native or pasteurized orchard soils artificially infested with the pathogen ${ }^{y}$

\begin{tabular}{|c|c|c|c|c|c|c|}
\hline \multirow[b]{2}{*}{ Treatment $^{\mathrm{Z}}$} & \multicolumn{2}{|c|}{ CV native soil } & \multicolumn{2}{|c|}{ WVC native soil } & \multicolumn{2}{|c|}{ WVC pasteurized soil } \\
\hline & Population $\left(\log _{10} \mathrm{CFU} \mathrm{g}^{-1}\right)$ & Infection $(\%)$ & Population $\left(\log _{10} \mathrm{CFU} \mathrm{g} \mathrm{g}^{-1}\right)$ & Infection $(\%)$ & Population $\left(\log _{10} \mathrm{CFU} \mathrm{g} \mathrm{g}^{-1}\right)$ & Infection $(\%)$ \\
\hline Control & $5.38 \mathrm{a}$ & $32 \mathrm{c}$ & $5.52 \mathrm{a}$ & $58 \mathrm{c}$ & 1.69 & $81 \mathrm{a}$ \\
\hline $\mathrm{DE}$ & $7.14 \mathrm{~b}$ & $14 \mathrm{ab}$ & $7.86 \mathrm{c}$ & $8 \mathrm{a}$ & ND & $89 \mathrm{a}$ \\
\hline IG & $7.42 \mathrm{~b}$ & $9 \mathrm{a}$ & $7.30 \mathrm{bc}$ & $14 \mathrm{ab}$ & 2.08 & $91 \mathrm{a}$ \\
\hline PG & $6.87 \mathrm{~b}$ & $16 \mathrm{~b}$ & $6.79 \mathrm{~b}$ & $30 \mathrm{~b}$ & ND & $96 \mathrm{a}$ \\
\hline
\end{tabular}

y Orchard designations: CV, Columbia View Experimental Orchard, Orondo, WA; and WVC, Wenatchee Valley College Research and Demonstration Orchard, E.

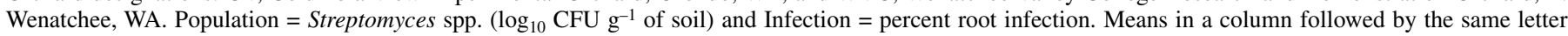
are not significantly different $(P>0.05 ; n=5) ;-$ indicates not determined; ND $=$ not detected (detection limit was 100 CFU g $\mathrm{g}^{-1}$ of soil).

${ }^{\mathrm{z}} \mathrm{DE}=$ Brassica napus cv. Dwarf Essex, AT = B. napus cv. Athena, $\mathrm{IG}=$ Sinapis alba cv. IdaGold, and PG = B. juncea cv. Pacific Gold. Seed meal was incorporated into soil 6 weeks prior to introduction of $R$. solani AG-5 inoculum. 
resulted in suppression or eradication of Streptomyces populations and elimination of disease control (Table 4).

Temporal dynamic of $B$. juncea PG-induced control of $\boldsymbol{R}$. solani AG-5. The efficacy of B. juncea PG for the control of $R$. solani AG-5 was dependent upon the timing of pathogen infestation relative to application of the amendment. When B. juncea PG amendment was incorporated into soil at the same time as pathogen infestation, the treatment significantly $(P<0.001)$ reduced $R$. solani infection of Gala seedling roots (Table 5). However, when introduction of the pathogen was delayed until $24 \mathrm{~h}$ post seed meal amendment, root infection was similar in the B. juncea PG-amended and nontreated soils (Table 5). Incubation of $B$. juncea PG-amended soil for 4 weeks prior to infestation with $R$. solani AG-5 resulted in the restoration of disease suppression. This reestablishment of disease control in B. juncea PGamended soil was associated with an increase in resident Streptomyces spp. numbers from $1.25 \times 10^{5} \mathrm{CFU} \mathrm{\textrm {g } ^ { - 1 }}$ of soil at day one to $3.75 \times 10^{7} \mathrm{CFU} \mathrm{g}^{-1}$ of soil in soils incubated for 4 weeks.

TABLE 5. Effect of duration of period between Brassica juncea cv. Pacific Gold seed meal (PG) amendment $(0.5 \% \mathrm{vol} / \mathrm{vol})$ and pathogen introduction on infection of 'Gala' seedlings grown in Columbia View orchard soil artificially infested with Rhizoctonia solani AG-5

\begin{tabular}{lcc}
\hline & \multicolumn{2}{c}{$R$. solani infection frequency $(\%)^{\mathrm{z}}$} \\
\cline { 2 - 3 } Treatment & Native soil & Pasteurized soil \\
\hline Control & $79 \mathrm{~b}$ & $44 \mathrm{~b}$ \\
PG incubation & $13 \mathrm{a}$ & $2 \mathrm{a}$ \\
$0 \mathrm{~h}$ & $62 \mathrm{~b}$ & $37 \mathrm{~b}$ \\
$24 \mathrm{~h}$ & $28 \mathrm{a}$ & - \\
4 weeks &
\end{tabular}

${ }^{\mathrm{z}}$ Means in a column followed by the same letter are not significantly different $(P>0.05 ; n=10) ;-$ indicates not determined.

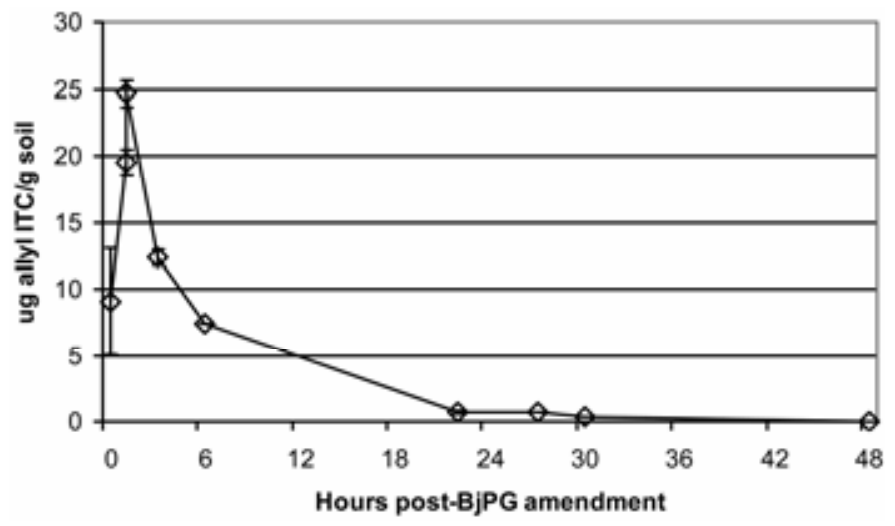

Fig. 1. Temporal pattern of allyl-isothiocyanate emission from Columbia View orchard soil amended with Brassica juncea cv. Pacific Gold seed meal (BjPG) as determined by monitoring concentration in the headspace of a chamber by gas chromatography. Seed meal was added to soil at a concentration of $0.5 \%$ $(\mathrm{vol} / \mathrm{vol})$. Bars $=$ standard deviation of the mean.
Pasteurization of soil prior to pathogen infestation did not diminish the initial disease control obtained in response to $B$. juncea $\mathrm{PG}$ amendment. When inoculum of $R$. solani AG-5 was introduced into pasteurized soil at the time of seed meal amendment, the infection rate for Gala seedlings cropped in this soil was significantly $(P=0.001)$ less than when the pathogen was introduced $24 \mathrm{~h}$ post seed meal amendment of pasteurized soil or in the no-seed meal control (Table 5).

When $R$. solani AG-5 oat grain inoculum was exposed to volatiles emanating from $B$. juncea PG-amended soil for the period 0 to $24 \mathrm{~h}$ post amendment, hyphal growth was completely inhibited. In contrast, hyphal growth from oat grain inoculum incubated in the presence of B. napus DE- or $S$. alba IG-amended soil was not significantly $(P>0.05)$ different from the control. When exposed to volatiles from the same soil during the period 24 to $48 \mathrm{~h}$ post seed meal amendment, hyphal growth of $R$. solani was equivalent for all treatments (data not shown). The temporal nature of fungal growth inhibition corresponded with the dynamics of allyl-isothiocyanate emission from B. juncea PGtreated soil (Fig. 1).

Effect of composite seed meal amendment on Pythium and Pratylenchus spp. Amendment of either CV or GC orchard soil with $B$. napus DE resulted in a rapid increase in populations of Pythium spp., with the response of greater magnitude in GC soil (Table 6). Co-application of B. napus with B. juncea seed meal effectively suppressed the Pythium-stimulating effect of B. napus DE. An equivalent response with regard to populations of Pythium spp. and root infection of seedlings grown in amended soils was observed whether $B$. juncea $\mathrm{PG}$ represented one-third or two-thirds of the total composite seed meal amendment applied to soils (Table 7). All seed meal amendments resulted in a similar suppression of lesion nematode numbers over the course of this short 2-week plant growth period (Table 7).

\section{DISCUSSION}

The formulation of economically viable and horticulturally acceptable nonfumigant measures for the control of tree fruit replant diseases is confounded by the biological complexity of these disease phenomena. However, once orchards are established, few other impediments to production, such as weed control, are difficult to resolve with the use of standard practices in conventional systems. The preplant application of B. napus seed meal in concert with a post plant application of mefenoxam for the control of apple replant disease previously was shown to be effective on sites where the causal fungal complex (21) acted alone to incite disease rather than in concert with the lesion nematode (25). The current studies were undertaken as a first step to identify an alternative seed meal or composite seed meal amendment capable of providing a broader level of activity against the spectrum of agents contributing to replant disease, and suitable for use in both organic and conventional orchard management systems.

TABLE 6. Effect of Brassica napus cv. Dwarf Essex (DE), Brassica juncea cv. Pacific Gold (PG), and composite seed meal amendments on populations of Pythium spp. (propagules $\mathrm{g}^{-1}$ of soil) recovered from replant orchard soils ${ }^{\mathrm{z}}$

\begin{tabular}{|c|c|c|c|c|c|c|c|c|}
\hline \multirow[b]{2}{*}{ Treatment } & \multicolumn{4}{|c|}{$\mathrm{CV}$ orchard } & \multicolumn{4}{|c|}{ GC orchard } \\
\hline & Day 0 & Day 3 & Day 7 & Day 14 & Day 0 & Day 3 & Day 7 & Day 14 \\
\hline Control & $25 \mathrm{a}$ & $25 \mathrm{a}$ & $0 \mathrm{a}$ & $75 \mathrm{a}$ & $0 \mathrm{a}$ & $50 \mathrm{a}$ & $25 \mathrm{a}$ & $25 \mathrm{a}$ \\
\hline $\mathrm{DE}$ & $25 \mathrm{a}$ & $525 \mathrm{~b}$ & $400 \mathrm{~b}$ & $275 \mathrm{~b}$ & $0 \mathrm{a}$ & $2,425 \mathrm{~b}$ & $3,500 \mathrm{~b}$ & $3,525 \mathrm{~b}$ \\
\hline DE+PG 1:1 & $0 \mathrm{a}$ & $0 \mathrm{a}$ & $0 \mathrm{a}$ & $0 \mathrm{a}$ & $0 \mathrm{a}$ & $125 \mathrm{a}$ & $125 \mathrm{a}$ & $25 \mathrm{a}$ \\
\hline DE+PG 1:2 & $0 \mathrm{a}$ & $25 \mathrm{a}$ & $0 \mathrm{a}$ & $0 \mathrm{a}$ & $0 \mathrm{a}$ & $75 \mathrm{a}$ & $0 \mathrm{a}$ & $75 \mathrm{a}$ \\
\hline $\mathrm{DE}+\mathrm{PG} 2: 1$ & $0 \mathrm{a}$ & $75 \mathrm{a}$ & $25 \mathrm{a}$ & $25 \mathrm{a}$ & $50 \mathrm{a}$ & $50 \mathrm{a}$ & $0 \mathrm{a}$ & $150 \mathrm{a}$ \\
\hline
\end{tabular}

${ }^{\mathrm{z}}$ Orchard designations: CV, Columbia View Experimental Orchard, Orondo, WA; and GC, commercial orchard, Manson, WA. Means in a column followed by the same letter are not significantly different $(P>0.05 ; n=4)$. Limit of detection for any individual soil sample equals 100 propagules $\mathrm{g}^{-1}$ of soil. 
Control of Rhizoctonia root rot of apple in response to B. napus seed meal amendment previously was shown to operate through the resident soil microbial community, with Streptomyces spp. likely possessing a functional role $(10,11)$. In the current study, capacity of each Brassicaceae seed meal examined to suppress root infection by $R$. solani AG-5 required activity of the native orchard soil biology. This included B. juncea seed meal, which also produces glucosinolate hydrolysis products previously shown to inhibit this fungal pathogen $(18,37)$, and provide control of damping-off incited by $R$. solani AG-4 (9). In the case of $B$. juncea $\mathrm{PG}$, the requirement for an active microbial community and the functional mode of action leading to disease control varied in a temporal manner. Disease control was achieved when $B$. juncea $\mathrm{PG}$ and $R$. solani were introduced into a soil system simultaneously, but no disease control was detected if pathogen infestation was delayed until $24 \mathrm{~h}$ post seed meal amendment. Suppression of $R$. solani during the initial $24 \mathrm{~h}$ period post amendment was not dependent upon the resident microbial community because the same temporal relationship in disease control was exhibited in both native and pasteurized soils. This pattern corresponded directly with the pattern of allyl isothiocyanate (AITC) release from B. juncea PG-treated soil; $>99 \%$ of AITC emission was recorded within $24 \mathrm{~h}$ of seed meal amendment, and growth of the pathogen was not impeded when exposed to volatiles released from the same soil 24 to $48 \mathrm{~h}$ after amendment. The B. juncea PG-treated soil, which was conducive to disease development when pathogen introduction was delayed until $24 \mathrm{~h}$ post amendment, reverted to the suppressive state when soil was incubated for 4 weeks prior to introduction of the pathogen. This event, as well as the control of $R$. solani AG-5 conferred by B. napus DE, B. napus AT, or S. alba IG soil amendment, was associated with an increase in Streptomyces spp. soil population. These findings are in agreement with previous, more definitive studies demonstrating the capacity of Streptomyces spp. to suppress infection of apple roots by $R$. solani AG-5 (10).

Suppression of root infection by $R$. solani in response to application of any of the seed meal amendments was fairly uniform across soils examined in this study. However, when studies were conducted in a manner that circumvented the period of pathogen exposure to AITC produced in response to soil amendment with $B$. juncea seed meal, the level of disease control achieved with $B$. juncea PG commonly was lower than one or more of the alternative seed meal amendments. Although populations of $R$. solani resident in the orchard site are not likely to evade exposure to AITC, sclerotia of $R$. solani are relatively tolerant of volatiles emanating from decomposing Brassicaceae residues (37) and may serve as a persistent reservoir of inoculum in $B$. juncea PG-treated soils. The resident soil microbial community also will recover (23), and the pattern of microbial succession ultimately may influence overall control of $R$. solani achieved with B. juncea PG amendment. The rapid emission of AITC from B. juncea PGtreated soils will be of significance in the post plant setting because $R$. solani commonly is associated with rootstocks of planting material used to establish the orchard (7). This potential source of pathogen inoculum would not be exposed to AITC generated in response to $B$. juncea seed meal amendment and, in this instance, $B$. napus seed meal could prove a more effective material for control of $R$. solani.

Although all seed meals suppressed initial lesion nematode soil populations, only $B$. juncea $\mathrm{PG}$ amendment resulted in a sustained suppression of root populations throughout a 6-month growth period. Lesion nematode population trends in B. napus seed mealtreated soils in this greenhouse study were similar to that observed in previous field studies, where initial nematode suppression was not maintained into the second growing season (25). Initial nematode suppression realized in response to all seed meal amendments could be attributed to the nematistatic properties of this and other high-N-content organic amendments $(27,31)$. The prolonged and sustained suppression of $P$. penetrans populations in $B$. juncea $\mathrm{PG}$ relative to $B$. napus $\mathrm{DE}$ or $S$. alba $\mathrm{IG}$ amendment is consistent with the known nematicidal activity of AITC produced by incorporation of this seed meal (38), and the lack of active ITCs produced in response to residues of B. napus (14) or S. alba (8).

Due to the associated increase in Pythium spp. root infection, effective application of $B$. napus DE for control of apple replant disease required a post plant application of mefenoxam (25), an approach not suitable for use in organic production systems. B. juncea PG was the only amendment that did not stimulate Pythium spp. populations and, when used in conjunction with B. napus seed meal, it suppressed the characteristic B. napus DEinduced stimulation of this community. Such a finding would suggest that $B$. juncea $\mathrm{PG}$ amendment, in and of itself, could be appropriate in organic systems. However, B. juncea PG was found to stimulate apple root infection by Phytophthora cambivora and P. megasperma in the field (M. Mazzola, unpublished data) whereas B. napus DE did not, and B. napus seed meals appear to provide superior control of $R$. solani. As such, based on these preliminary trials, a composite $B$. juncea $\mathrm{PG}$ and $B$. napus $\mathrm{DE}$ amendment may be more suitable for application in organic systems.

Findings from the current study suggest that the use of Brassicaceae seed meal amendments has promise as an alternative strategy for the control of apple replant disease, and that disease control can be realized in a predictable manner. Amendment rates employed in this and previous studies $(10,11,24,25)$ are equivalent to the application of seed meal at 8 to $10 \mathrm{tha}^{-1}$. These rates equate to an amount that ranges from $<1$ to $25 \%$ of that recently used in the evaluation of composts in greenhouse, apple orchard, and other field-level production systems $(5,33,36,37)$. Seed meal sourced from the same Brassica sp. (B. napus) but different cultivars (B. napus DE and B. napus AT) or of the same cultivar (B. napus DE) over multiple years consistently has provided the same level and spectrum of disease suppression $(24,25)$. In addition, although these seed meals operate in part through the resident soil microbial community, a similar spectrum of pathogen control has been observed in all orchard soils examined. Biological function of amendments in only specific soils (34) can, at times, limit their value as a disease control option. Populations of one proposed functional microbial group active in control of $R$. solani, resident streptomycetes, were consistently amplified in these studies regardless of orchard soil, and have been maintained in the field for upwards of two full growing seasons (11). Such consistency in product, both in terms of composition and activity, an attribute often lacking in organic amendments (13), may enhance the adoption of their use in commercial orchard production systems upon demonstration of functionality in field trials.

TABLE 7. Effect of Brassica napus cv. Dwarf Essex (DE) and B. juncea cv. Pacific Gold (PG) seed meal amendments or their composite at varying ratios on percent Pythium spp. root infection and recovery of Pratylenchus spp. (number $\mathrm{g}^{-1}$ of root) from 'Gala' apple seedlings ${ }^{\mathrm{z}}$

\begin{tabular}{lccc}
\hline & \multicolumn{2}{c}{ Pythium root infection $(\%)$} & \\
\cline { 2 - 3 } Treatment & CV orchard & GC orchard & GC, Pratylenchus spp. \\
\hline Control & $7 \mathrm{a}$ & $8 \mathrm{a}$ & $252 \mathrm{~b}$ \\
DE & $31 \mathrm{~b}$ & $45 \mathrm{~b}$ & $56 \mathrm{a}$ \\
PG & $0 \mathrm{a}$ & $3 \mathrm{a}$ & $4 \mathrm{a}$ \\
DE+PG 1:1 & $1 \mathrm{a}$ & $8 \mathrm{a}$ & $21 \mathrm{a}$ \\
DE+PG 1:2 & $6 \mathrm{a}$ & $5 \mathrm{a}$ & $3 \mathrm{a}$ \\
DE+PG 2:1 & $1 \mathrm{a}$ & $7 \mathrm{a}$ & $25 \mathrm{a}$ \\
\hline
\end{tabular}

${ }^{\mathrm{z}}$ Orchard designations: CV, Columbia View Experimental Orchard, Orondo, WA; and GC, commercial orchard, Manson, WA. Means in the same column followed by the same letter are not significantly different $(P>0.05 ; n=10)$. 


\section{ACKNOWLEDGMENTS}

Funding for the conduct of this research was provided by the United States Department of Agriculture CSREES Organic and Integrated Grants Program and the Washington Tree Fruit Research Commission. We thank S. Ivanov for excellent technical support; and J. Mattheis, D. Rudell, and D. Buchanan for providing technical assistance in measurement of ITC emissions from soil.

\section{LITERATURE CITED}

1. Angus, J. F., Gardner, P. A., Kirkegaard, J. A., and Earchelier, J. M. 1994. Biofumigation: Isothiocyanates released from Brassica roots inhibit growth of the take-all fungus. Plant Soil 162:107-112.

2. Brown, J., Davis, J. B., Erickson, D. A., Brown, A. P., and Seip, L. 1997. Registration of 'IdaGold' mustard. Crop Sci. 38:541.

3. Brown, J., Davis, J. B., Erickson, D. A., Seip, L., and Gosselin, T. 2004. Registration of 'Pacific Gold' condiment yellow mustard. Crop Sci. 44:2271-2272.

4. Brown, J., Wysocki, D., Davis, J. B., Erickson, D. A., Seip, L., Ott, S., and Gosselin, T. 2004. Registration of 'Athena' winter rapeseed. Crop Sci. 45:800-801

5. Brown, M. W., and Tworkoski, T., 2004. Pest management benefits of compost mulch in apple orchards. Agric. Ecosyst. Environ. 103:465-472

6. Brown, P. D., and Morra, M. J. 1997. Control of soil-borne plant pests using glucosinolate-containing plants. Adv. Agron. 61:167-231.

7. Burr, T. J., Hunter, J. E., Ogawa, J. M., and Abawi, G. S. 1978. A root rot of apple caused by Rhizoctonia solani in New York nurseries. Plant Dis. Rep. 62:476-479.

8. Buskov, S., Serra, B., Rosa, E., Sørensen, H., and Sørensen, J. C. 2002. Effects of intact glucosinolates and products produced from glucosinolates in myrosinase-catalyzed hrdrolysis on the potato cyst nematode (Globodera rostochiensis cv. Woll). J. Agric. Food Chem. 50:690-695.

9. Chung, W. C., Huang, J. W., Huang, H. C., and Jen, J. F. 2002. Effect of ground Brassica seed meal on control of Rhizoctonia damping-off of cabbage. Can J. Plant Pathol. 24:211-218.

10. Cohen, M. F., and Mazzola, M. 2006. Resident bacteria, nitric oxide emission and particle size modulate the effect of Brassica napus seed meal on disease incited by Rhizoctonia solani and Pythium spp. Plant Soil 286:75-86.

11. Cohen, M. F., Yamasaki, H., and Mazzola, M. 2005. Brassica napus seed meal soil amendment modifies microbial community structure, nitric oxide production and incidence of Rhizoctonia root rot. Soil Biol. Biochem. 37:1215-1227.

12. Dropkin, V. H. 1980. Introduction to Plant Nematology. John Wiley \& Sons, New York.

13. Hoitink, H. A. J., and Boehm, M. J. 1999. Biocontrol within the context of soil microbial communities: A substrate-dependent phenomenon. Annu. Rev. Phytopathol. 37:427-446.

14. Johnson, A. W., Golden, A. M., Auld, D. L., and Sumner, D. R. 1992. Effect of rapeseed and vetch as green manure crops and fallow on nematodes and soil-borne pathogens. J. Nematol. 24:117-126.

15. Kirkegaard, J. A., and Matthiessen, J. N. 2004. Developing and refining the biofumigation concept. Agroindustria 3:233-239.

16. Lazzeri, L., Baruzzi, G., Malaquiti, L., and Antoniacci, L. 2003. Replacing methyl bromide in annual strawberry production with glucosinolate-containing green manure crops. Pest Manage. Sci. 59:983-990.

17. Lewis, J. A., and Papavizas, G. C. 1971. Effect of sulfur-containing volatile compounds and vapors from cabbage decomposition on Aphanomyces euteiches. Phytopathology 61:208-214.

18. Manici, L. M., Lazzeri, L., Baruzzi, G., Leoni, O., Galletti, S., and Palmieri, S. 2000. Suppressive activity of some glucosinolate enzyme degradation products on Pythium irregulare and Rhizoctonia solani in sterile soil. Pest Manage. Sci. 56:921-926.
19. Manici, L. M., Lazzeri, L., and Palmieri, S. J. 1997. In vitro fungitoxic activity of some flucosinolates and their enzyme-derived products toward plant pathogenic fungi. J. Agric. Food Chem. 45:2768-2773.

20. Mayton, H. S., Olivier, C., Vaughn, S. F., and Loria, R. 1996. Correlation of fungicidal activity of Brassica species with allyl isothiocyanate production in macerated leaf tissue. Phytopathology 86:267-271.

21. Mazzola, M. 1998. Elucidation of the microbial complex having a causal role in the development of apple replant disease in Washington. Phytopathology 88:930-938.

22. Mazzola, M. 1999. Transformation of soil microbial community structure and Rhizoctonia-suppressive potential in response to apple roots. Phytopathology 89:920-927.

23. Mazzola, M., Cohen, M. F., and Brown, J. 2005. Effect of Brassicaceae seed meals on microbial communities and growth of apple in replant soils. (Abstr.) Phytopathology 95:S67.

24. Mazzola, M., Granatstein, D. M., Elfving, D. C., and Mullinix, K. 2001. Suppression of specific apple root pathogens by Brassica napus seed meal amendment regardless of glucosinolate content. Phytopathology 91:673679.

25. Mazzola, M., and Mullinix, K. 2005. Comparative field performance of measures containing Brassica napus seed meal or green manure for the management of apple replant disease. Plant Dis. 89:12071213.

26. Mazzola, M., Wong, O. T., and Cook, R. J. 1996. Variation in virulence among isolates of Rhizoctonia oryzae and $R$. solani AG-8 on wheat and detection of $R$. oryzae in plant tissue by PCR. Phytopathology 86:354360.

27. Noble, R., and Coventry, E. 2005. Suppression of soil-borne plant diseases with composts: A review. Biocontrol Sci. Technol. 15:3-30.

28. Oka, Y., and Pivonia, S. 2002. Use of ammonia-releasing compounds for control of the root-knot nematode Meloidogyne javanica. Nematology 4:65-71.

29. Papavizas, G. C. 1966. Suppression of Aphanomyces root rot of peas by cruciferous soil amendments. Phytopathology 56:1071-1075.

30. Pascual, J. A., Ros, M., Fernandez, P., Bernal, A., and Lacassa, A. 2004. Future of compost as an alternative to chemical compounds in ecological agriculture. Pages 251-262 in: Waste Management and the Environment II. C. A. Brebbia, S. Kungolos, V. Popov, and H. Itoh, eds. WIT Press, Southampton, UK.

31. Potter, M. J., Davies, K., and Rathjen, A. J. 1998. Suppressive impact of glucosinolates in Brassica vegetative tissues on root lesion nematode Pratylenchus neglectus. J. Chem. Ecol. 24:67-80.

32. Rodríguez-Kabana, R. 1986. Organic and inorganic nitrogen amendments to soil as nematode suppressants. J. Nematol. 18:129-135.

33. Stone, A. G, Vallad, G. E., Cooperband, L. R., Rotenberg, D., Darby, H. M., James, R. V., Stevenson, W. R., and Goodman, R. M. 2003. Effect of organic amendments on soilborne and foliar diseases in field-grown snap bean and cucumber. Plant Dis. 87:1037-1042.

34. Tenuta, M., and Lazarovits, G. 2002. Ammonia and nitrous acid from nitrogenous amendments kill microsclerotia of Verticillium dahliae. Phytopathology 92:548-552.

35. Warton, B., Matthiessen, J. N., and Shackleton, M. A. 2003. Crossenhancement: Enhanced biodegradation of isothiocyanates in soils previously treated with metham sodium. Soil Biol. Biochem. 35:11231127.

36. Yao, S., Merwin, I. A., Abawi, G., and Theis, J. E. 2006. Soil fumigation and compost amendment alter soil microbial community composition but do not improve tree growth or yield in an apple replant site. Soil Biol. Biochem. 38:587-599.

37. Yulianti, T. K., Sivasithamparam, K., and Turner, D. W. 2006. Response of different forms of propagules of Rhizoctonia solani AG2-1 (ZG5) exposed to the volatiles produced in soil amended with green manures. Ann. Appl. Biol. 148:105-111.

38. Zasada, I. A., and Ferris, H. 2004. Nematode suppression with Brassicaceous amendments: Application based upon glucosinolate profiles. Soil Biol. Biochem. 36:1017-1024. 